\title{
Study on Influence of Learning Engagement to Employability of Students Upgraded from College to University in Beijing
}

\author{
Yingxia Luo, Xiaoju Zhang \\ Beijing Union University, Beijing, China \\ Email: mlbsabc@sina.com
}

How to cite this paper: Luo, Y. X., \& Zhang, X. J. (2017). Study on Influence of Learning Engagement to Employability of Students Upgraded from College to University in Beijing. Creative Education, 8, 1523-1532.

https://doi.org/10.4236/ce.2017.89106

Received: June 20, 2017

Accepted: July 28, 2017

Published: July 31, 2017

Copyright ( 92017 by authors and Scientific Research Publishing Inc. This work is licensed under the Creative Commons Attribution International License (CC BY 4.0). http://creativecommons.org/licenses/by/4.0/

\begin{abstract}
Students upgraded from college to university are the outstanding group among college students. Their study status, future employability and career development direction are different from those of college students or undergraduates, which deserves particular concern. Based on The Survey on the Development Status of Students Upgraded from College to University in Beijing in 2014, this study analyzes students' learning engagement, employability as well as the relationship between the two. It shows that, on the whole, students upgraded from college to university learn positively and their learning motivation presents the dual motivations for achieving success and avoiding failure (An, Cheng, \& Sun, 2009). Their learning attitude and objectives to improve abilities play a key role in their employability.
\end{abstract}

\section{Keywords}

Students Upgraded from College to University, Learning Engagement, Employability, Learning Objectives/Target

\section{Introduction}

The National Medium and Long-Term Educational Reform and Development Plan (2010-2020) makes it clear that education quality should be highly valued, especially higher education. The higher education in China has witnessed its transition from elite-oriented to mass-oriented. As the quality of higher education has significantly declined (Xie, 2010), graduates have lower social acceptance and inadequate employability. The major problem is the college students' sharp reduce in learning engagement (Sun, 2009). Arguably, college students have limited experience in the labor market and the college education has a delayed effect (Fredricks, Blumenfeld \& Paris, 2004) partly because colleges and 
students pay more attention to their learning ability (the ability to acquire knowledge), but less attention to cultivating their general ability, which is closely related to the whole education system in China that has less awareness and cultivation of students' general ability. In the Analects, Confucius said, "It is indeed a pleasure to acquire knowledge and, as you go on acquiring, to put into practice what you have acquired." Many modern Chinese misinterpret it as "It is a pleasure to learn and at due times to review what one has learned, isn't it?" But based on the specific historical background and context, what Confucius intended to express was a process from learning to practicing, which implied the process from theory to practice and the refuge from thought to behavior. However, for thousands of years, this misinterpretation has been dominating in the fields of education. As a result, education system in China has been paying less attention to students' general ability of practice. Since 2000, for the talents cultivation in higher education, industries have been focusing on measuring the employees' basic capabilities and employability. The assessment of graduates contributes to improvement of higher education and draws more attention to the process of educating and learning.

At the same time, employers expect graduates to be equipped with various skills and employability (Liao, 2011a). In response to social accountability, employability is taken as higher education's mission; the employers are regarded as the most direct and closest assessors and the employers' demands are included in an item of higher education assessment as their direction of educational development. The core task for college students is to promote their employability to be ready for employment. Thus it becomes the common needs of colleges, employers and employees to improve the college students' employability.

Students upgraded from college to university are regarded as a special group who deserves particular attention. Based on The Survey on the Development Status of Students Upgraded from College to University in Beijing in 2014, this study attempts to investigate students' learning engagement from college to university and analyze the employability output by learning, hoping to put forward the specific suggestions on improving education administration from college to university (Wang, 2011).

\section{Comments on Pre-Researches}

\subsection{The Concept of "Employability"}

In the early $20^{\text {th }}$ century of Western civilizations, Beveridge first put forward the term "employability" (some researchers translated as the ability of employment or the ability to be employed.) referring to the ability to do physical work. In the later decades, its concept and connotation had been increasingly enriched according to X, Y. In the 1980s, "employability" had developed from the initial competence to comprehensive capabilities of knowledge, attitude, professional skills and so on. Its connotation gradually extended from employees' simple ability to multiple abilities, the employers' demands and the potential of labor market, which made it become a concept of public policy meaning (Liao, 2011a). 
So far, there has been little consensus on its definition of "employability". From the perspective of characteristics, Little defined "employability" as a general term of achievement, capacity and personal attributes that help people to successfully find a job. Yorke, from the perspective of development, thought the key of "employability" is the possibility that it is possible to be converted into successful employment, but there not a series of features that can convert the "employability" into the real employment. Hillage and Pollard from their own and others' perspectives (Liao, 2011b), put that "employability" was the ability of gaining initial employment, maintaining the current employment and obtaining new employment if necessary. They considered that it was not enough for the employees to possess the required knowledge and skills. The ability to perform their abilities, i.e. the transferable skills, is also needed. From the view of integration, Yorke thought the knowledge and skills of "employability" have rich meanings. Although research on "employability" started late in China, "employability" has been defined based on the national condition of China. Tian Weidong from the perspective of capability defined it as the work-related ability that the students get from learning and practicing. Xie Z. Y., from the perspective of correlation, further defined "employability" as comprehensive abilities including knowledge, skills, attitude and so on (Zhang, 2012). Li J., from the perspective of quality, defined the college students' "employability" as the quality of the ability that enables them access to employment opportunities, which is a combined performance of social learning and individual quality (Tian, 2002).

The representative definition of "employability" is the point of Hillage and Pollardde at present. On this basis, Song (2008) defined it as various individual qualities that help obtain, maintain employment, find re-employment and do well in their jobs, which are included in the initial employment capacity and future competency. Song G. X. further pointed out that the proper understanding of "employability" should be the combination of general and professional skills. This paper will adopt Hillage and Pollardde's definition of "employability" that it is the ability of gaining initial employment, maintaining the present employment and obtaining new employment if necessary as well as divide it into general and professional skills (Su, 2014).

\subsection{The Factors Influencing Employability}

Most of the studies on the factors of influencing employability still stay purely theoretical, short of complete, systematic and empirical research according to researchers such as (X, y and $\mathrm{x}$ ). Liu S. T. and Yin X. P. summarized them as social individual factors. Social factors mainly include national policies, social and economic situation, education, the trend of social selection and so on. Individual factors are special factors like quality, ability, psychology, behaviors, etc. that have direct or indirect, positive or negative effects on the college students in job-hunting. It mainly includes graduates' comprehensive quality, employment psychology, job-hunting methods and so on. Individual factors as subjective factors are key factors affecting employment of college students, which play a 
significant part in employment of college students.

Based on the factors of perceptible employability, Sun J. further refined the individual factors and she argued that individual employability is the basis for learning ability, social practice, interpersonal communication, and the abilities of organization and management, etc.

\subsection{The Research on Learning Engagement}

Fredrick (2004) adopted different dimensions to define learning engagement. In his view, learning engagement should be divided into three dimensions: behavioral, emotional and cognitive. Behavioral engagement mainly refers to students' intensity of participation and performance in school activities including academic or non-academic ones. Emotional engagement is also called psychological engagement, mainly referring to students' positive or negative emotional responses and attitudes to their study, school, teachers and classmates. Cognitive engagement is students' thoughts and willingness to make efforts to understand complicated ideas and master difficult skills, which is regarded as students' learning strategies. Fredrick further pointed out that the three dimensions are supposed to be independent and interactive. The students tend to do better in behavioral and cognitive engagement (Xie, 2005).

\section{The Study of Analysis Framework and Data Sources}

The objective of the study is to discuss the relationship between students' learning engagement and their employability. Sun (2010) believed that social learning theory could account for individual cognitive, behavior and environment factors and their interactive influences on human behavior. The expectations of success depend on three factors: one's previous experience in certain circumstances, the changes of prior experience in no particular and people's perceptions of specific task features.

Suppose employability includes two parts: general and professional skills; the factors influencing employability include students' motivations for learning (motivations for achieving success and avoiding failure), learning attitude and behavior, and learning objectives ( $\mathrm{Li}, 2010)$.

The data in this study are collected from The Survey on Students' Academic Development Status in Bejing from College to University Initiated and Implemented by the research group in 2014. The study covered by four typical colleges upgrading from college to university in Beijing: Beijing Union University, North China University of Technology (NCUT), Beijing City University and Beijing Institute of Petrochemical Technology (Liu, 2001). Beijing Union University has the largest scale in upgrading from college to university in Beijing with the most majors and the most complete subjects and it mainly accepts those graduates from their own college and other colleges. North China University of Technology (NCUT) is the second largest college in upgrading from college to university in Beijing, which mainly accepts those graduates in higher vocational colleges with some industry background. Beijing City University is the third largest col- 
lege in upgrading from college to university in Beijing, which mainly accepts those graduates from their own college. Beijing Institute of Petrochemical Technology is a college with specific industry characteristics in upgrading from college to university in Beijing, whose graduates are mainly from the higher vocational colleges in petroleum industry. The four colleges mentioned above have their own features in cultivating talents, which are the representatives of upgrading from college to university in Beijing. Stratified sampling method was conducted in the survey to select samples by institutions, majors, males and females. Except for those invalid questionnaires with incomplete information, 861 out of the total 1120 were valid and analyzed in the survey, among which males accounted for $27.8 \%$ and females $71.5 \%$; the gender imbalance is accidental.

\section{The Findings and Analysis on the Survey}

\subsection{The Status of College Students' Improvement in Employability during the Undergraduate}

In the questionnaire, 12 indexes are designed for the employability on 5-grade scoring criteria (Grade 1 for no improvement, Grade 5 for great improvement). The students are required to make selections in turn according to their own actual condition. The results are as follow: less than $4 \%$ college students do not think they have improvements in their abilities; less than $8 \%$ think they have improved a little; about 30\% don't care about their improvement in various abilities; $30 \%-40 \%$ have made certain or moderate improvement in their lifelong abilities; about $30 \%$ think they have made great improvement (Table 1).

Every index shows that the improvement in the abilities tends to be regular: a

Table 1. The status of college students' improvement in employability (\%).

\begin{tabular}{|c|c|c|c|c|c|c|}
\hline Dimensions & Indexes & No & $\begin{array}{l}\text { Little } \\
(\%)\end{array}$ & $\begin{array}{c}\text { Unimportant } \\
(\%)\end{array}$ & $\begin{array}{c}\text { Moderate } \\
(\%)\end{array}$ & $\begin{array}{l}\text { Great } \\
(\%)\end{array}$ \\
\hline \multirow{5}{*}{$\begin{array}{l}\text { Professional } \\
\text { skills }\end{array}$} & Knowledge and vision expansion & 3.8 & 6.2 & 29.3 & 31 & 29.5 \\
\hline & Mastery of basic knowledge and theory of professional discipline & 1.9 & 7.4 & 27.7 & 34.1 & 28.7 \\
\hline & Operational and practical ability in the fields of professional discipline & 2.3 & 6.3 & 28.8 & 35.5 & 26.8 \\
\hline & Problem-solving ability through the comprehensive knowledge learned & 1.2 & 6.2 & 27.9 & 37.3 & 27.5 \\
\hline & Information processing capability such as computer & 1.3 & 6.8 & 27.9 & 35.6 & 28.4 \\
\hline \multirow{9}{*}{$\begin{array}{c}\text { General } \\
\text { skills }\end{array}$} & Clear and effective oral expression & 1.2 & 6.2 & 27.9 & 37.2 & 27.4 \\
\hline & Ability of applied writing & 2.0 & 8.2 & 29.3 & 35.1 & 25.2 \\
\hline & Ability of social communication and how to get along with people & 1.4 & 5.8 & 25.6 & 37.8 & 29 \\
\hline & Respect and understand the groups from different regions and social cultures & 1.1 & 6.8 & 23.7 & 36 & 32.2 \\
\hline & Learning ability & 1.2 & 6.2 & 25.9 & 37.6 & 28.9 \\
\hline & Ability to identify and solve problems & 1.6 & 4.3 & 26.9 & 35.5 & 31.3 \\
\hline & Self-confidence & 1.5 & 6.5 & 27.6 & 34.4 & 29.8 \\
\hline & Self-management ability & 1.5 & 5.6 & 26.5 & 35.4 & 30.8 \\
\hline & Innovation ability & 3.2 & 6.7 & 27.8 & 33.7 & 28.4 \\
\hline
\end{tabular}


small percentage of students have no or little improvement, most of them have certain or moderate improvement while about $30 \%$ are indifferent to their abilities maybe because they don't take the questionnaire seriously or they don't know themselves well enough to make the choices.

\subsection{Students' Motivations for the Enrollment from College to University}

In the questionnaire, the motivations for the enrollment were across three dimensions: motivations for avoiding failure, achieving success and conformity. Five indexes were designed on five-grade scoring criteria (Grade 1 for unimportant, Grade 5 for quite important). The students were required to make selections in turn according to their own actual motivations. From the findings of the survey, more than $30 \%$ college students had motivations for avoiding failure; more than 50\% improved their academic levels for a good job; $29.9 \%$ made further education for their interests in academic learning and $10.9 \%$ fell into the herd mentality and followed others' choice. In general, the students who conducted a questionnaire survey had strong motivation for achieving success (Song, 2008) (Table 2).

\subsection{Students' Learning Objectives Upgraded from College to University}

In the questionnaire, students' learning objectives are divided into two dimensions: improve professional skills and general skills. Eleven indexes are set on five-grade scoring criteria (Grade 1 for unimportant, Grade 5 for quite important). The students are required to make selections in turn according to their own actual motivations. From the findings of the survey, less than 5\% college students think it unimportant in improving their skills (11.6\% think it unimportant in the index of studying abroad or graduate examination); nearly $30 \%$ think it is of moderate importance in improving their skills; $20 \%-40 \%$ think it quite important in improving all the skills (Table 3). In general, the students upgraded from college to university widely believe that it is important in skills' improvement.

Table 2. Students' motivations for enrollment from college to university (\%).

\begin{tabular}{|c|c|c|c|c|c|c|}
\hline Dimensions & Indexes & Unimportant & $\begin{array}{c}\text { Less } \\
\text { important } \\
(\%)\end{array}$ & $\begin{array}{c}\text { Doesn't } \\
\text { matter } \\
(\%)\end{array}$ & $\begin{array}{c}\text { Moderate } \\
\text { important } \\
\text { (\%) }\end{array}$ & $\begin{array}{c}\text { Quite } \\
\text { importan } \\
(\%)\end{array}$ \\
\hline \multirow{3}{*}{$\begin{array}{l}\text { Motivations for } \\
\text { avoiding failure }\end{array}$} & Relieve the employment pressure & 13.6 & 9.7 & 23.2 & 21 & 32.4 \\
\hline & Under family pressures & 33.5 & 17.2 & 23.5 & 11.7 & 14 \\
\hline & Make up for the failure of the college entrance examination & 15.9 & 8.2 & 22.2 & 22.3 & 31.1 \\
\hline \multirow{2}{*}{$\begin{array}{l}\text { Motivations for } \\
\text { achieving success }\end{array}$} & Improve the academic levels for a good job & 3.5 & 7.4 & 11.8 & 25.7 & 51.3 \\
\hline & Satisfy the interests in further academic learning & 9.1 & 9.3 & 24.7 & 26.7 & 29.9 \\
\hline $\begin{array}{l}\text { Motivations for } \\
\text { conformity }\end{array}$ & My choice follows other students from college to university & 42.5 & 16.9 & 18.6 & 11 & 10.9 \\
\hline
\end{tabular}


Table 3. Students' learning objectives upgraded from college to university.

\begin{tabular}{|c|c|c|c|c|c|c|}
\hline Dimensions & Indexes & unimportant & $\begin{array}{c}\text { Less } \\
\text { important } \\
(\%)\end{array}$ & $\begin{array}{c}\text { Doesn't } \\
\text { matter } \\
(\%)\end{array}$ & $\begin{array}{c}\text { Moderate } \\
\text { important } \\
\text { (\%) }\end{array}$ & $\begin{array}{c}\text { Quite } \\
\text { important } \\
(\%)\end{array}$ \\
\hline \multirow{5}{*}{$\begin{array}{c}\text { Improve } \\
\text { professional skills }\end{array}$} & Master the knowledge and skills in the future careers & 4.9 & 7.5 & 23.3 & 26.9 & 37.4 \\
\hline & Pass graduate examination or study aboard & 11.6 & 14.7 & 31.4 & 21.7 & 20.5 \\
\hline & $\begin{array}{l}\text { Widely master and understand the knowledge of the academic } \\
\text { field }\end{array}$ & 2.1 & 7.5 & 23.5 & 32 & 34.8 \\
\hline & $\begin{array}{l}\text { Strengthen the ability to solve practical problems through the } \\
\text { comprehensive knowledge learned }\end{array}$ & 1.5 & 6.2 & 25.2 & 30.3 & 36.5 \\
\hline & Pass professional qualification certificate examinations & 3.5 & 7.5 & 27 & 29.2 & 32.8 \\
\hline \multirow{5}{*}{$\begin{array}{l}\text { Improve general } \\
\text { skills }\end{array}$} & Improve self-awareness and self-understanding & 2.0 & 6.7 & 23.5 & 29.1 & 35.8 \\
\hline & Improve the ability to deal with people & 2.3 & 5.1 & 22.4 & 31.6 & 38.5 \\
\hline & Build meaningful and interpersonal relationships & 2.9 & 7.2 & 24 & 28.6 & 37.2 \\
\hline & Enhance the understanding and adaptability to the society & 2.1 & 6.1 & 22.3 & 29 & 40.4 \\
\hline & Develop own interests in certain fields & 2.9 & 7.8 & 25.5 & 28 & 35.5 \\
\hline
\end{tabular}

\subsection{Students' Learning Attitude and Behavior}

In the questionnaire, students' learning attitude and behavior are divided into positive and negative attitude. The indexes are designed on five-grade scoring criteria (Grade 1 for never, Grade 5 for often). From the findings of the survey, except the preview before class, among the positive indexes, 30\% college students don't take their own learning attitude and behavior seriously; $30 \%$ are active in learning attitude and behavior in spite of the differences in different indexes; as far as negative attitude is concerned, nearly half are not negative to their learning attitude and behavior (Table 4). The differences in the indexes are probably related to students' habits of learning.

\subsection{Multivariate Linear Regression Analysis on Employability}

The data above shows students' learning engagement and the status of their employability. Therefore, this study focuses on the relationship between learning engagement (learning process) and employability (educational outcomes). The study considers students' employability as dependent variable while their learning motivation, objectives, attitude and behavior as independent variable (in Table 5).

The multivariate linear regression analysis on employability is shown in Table 6. Seen from the results, learning motivations do not go into the regression equation whether are for achieving success or for avoiding failure, but three independent variables (active learning attitude and behavior, improvement in general skills and professional skills) go into it. $34.8 \%$ accounts for professional skills; $34.8 \%$ accounts for active learning attitude and behavior, and improvement in general skills which go into the regression equation. Statistically, the core factors are not the influence of internal motivations on educational outcomes but students' learning attitude, behavior and objectives (Table 6). 
Table 4. Students' learning attitude and behavior.

\begin{tabular}{|c|c|c|c|c|c|c|}
\hline Dimensions & Indexes & Never & $\begin{array}{l}\text { Seldom } \\
(\%)\end{array}$ & $\begin{array}{l}\text { Doesn't matter } \\
(\%)\end{array}$ & $\begin{array}{l}\text { Frequent } \\
(\%)\end{array}$ & $\begin{array}{c}\text { Often } \\
(\%)\end{array}$ \\
\hline \multirow{13}{*}{ Positive attitude } & Preview before class & 11.4 & 25.8 & 34.7 & 15.9 & 11.9 \\
\hline & Actively ask and answer the questions in class & 6.6 & 24.1 & 35.3 & 21.8 & 12 \\
\hline & Make reports in class & 5.8 & 18.2 & 36.4 & 23.2 & 16.3 \\
\hline & Make notes carefully in class & 1.9 & 9.6 & 28.6 & 31.4 & 28.5 \\
\hline & Take an active part in group work or discussion in class & 2.0 & 8.3 & 30.7 & 34.2 & 24.9 \\
\hline & Further study academic problems you are interested in even after the courses & 2.8 & 10.6 & 33.8 & 30.1 & 22.7 \\
\hline & Continue to learn the courses with weak theory in spare time & 2.9 & 14.7 & 35.1 & 28.1 & 19.2 \\
\hline & $\begin{array}{l}\text { Take advantage of practicing to improve academic and comprehensive } \\
\text { ability }\end{array}$ & 3.0 & 10.7 & 33.5 & 31.7 & 21 \\
\hline & Actively utilize library resources & 4.6 & 14.8 & 34.3 & 27.4 & 18.9 \\
\hline & Consult the teachers about specific questions & 6.3 & 16.2 & 36 & 25.5 & 16 \\
\hline & Engaged in the learning activities on the Internet & 4.3 & 13.3 & 36.5 & 28.1 & 17.7 \\
\hline & Willing to invest a lot of time in learning & 4.9 & 9.4 & 33.1 & 27.8 & 24.8 \\
\hline & Feel ashamed to fail the exams & 6.7 & 9.3 & 21.6 & 23.4 & 39 \\
\hline \multirow{5}{*}{ Negative attitude } & Use PCs or mobile phones to chat or entertain on the Internet in class & 13.9 & 25.4 & 30.8 & 18.6 & 11.3 \\
\hline & Plagiarize assignments or internship reports & 31.5 & 24.1 & 22.5 & 15.1 & 6.9 \\
\hline & Not finish the assignments on time & 43.2 & 19.0 & 17.6 & 13.1 & 7.0 \\
\hline & $\begin{array}{l}\text { Do nothing with class; } \\
\text { not actively use the library resources }\end{array}$ & 27.0 & 28.0 & 24.9 & 13.1 & 7.0 \\
\hline & Skip classes & 49 & 15.2 & 15.9 & 11.7 & 8.3 \\
\hline
\end{tabular}

Table 5. Variable definition of employability model.

\begin{tabular}{ccc}
\hline & & Dependent variable \\
\hline Educational outcomes & Employability & Professional/general skills \\
& & Independent variable \\
Internal characteristics & Learning motivation upgraded from college to university & Motivation for achieving success/avoiding failure \\
External characteristics & Learning objectives & Professional/general knowledge target \\
& Learning attitude and behavior & Positive/negative attitude \\
\hline
\end{tabular}

Table 6. Relationship between employability and learning objectives and attitude.

\begin{tabular}{|c|c|c|c|c|c|}
\hline Dependent variable & Predictive variable & $\mathrm{R}$ & $\mathrm{R}^{2}$ & $\mathrm{~F}$ & $\mathrm{~T}$ \\
\hline \multirow{2}{*}{ Professional abilities } & Active learning attitude and behavior & & & & $10.427^{* * *}$ \\
\hline & The objective to improve professional skills & & & & $2.630^{* * *}$ \\
\hline
\end{tabular}

\section{Conclusions and Recommendations}

The students ungraded from college to university are the outstanding group among college students, who have access to their undergraduate studies through 
selective examinations. Their learning attitude, behavior and future employability just attracted attention in the whole higher education. The data analysis of this study based on the survey is of great importance for higher education industry to get into this group and their specific characteristics. The detailed research conclusions are summarized as follows:

Firstly, the study finds that the students ungraded from colleges to universities in Beijing widely have strong motivations for learning, for achieving success and avoiding failure as well as the minority for conformity. Colleges choices are students' decision for themselves, but the motivations behind tend to be multiple. Although these motivations have no direct impact on students' current employability, it may be a different story in the long term of their development, which needs further investigation (Wei, 1998).

Secondly, the students ungraded from colleges to universities are found that they widely have active learning attitude and behavior, take an active part in class discussion, take advantage of libraries or teachers to help their learning, and take the initiative to the assignments. Few have negative learning attitude and behavior. On the whole, the colleges have favorable attitude to learning.

Finally, based on regression analysis on the relationship between learning engagement and employability, it is found that students' motivations for learning have no obvious effects, but objective, behavior and attitude are vital. Active learning attitude and behavior as well as the objective to improve general skills play the critical role in general abilities. At the same time, active learning and behavior, the objectives to improve general and professional skills are the key to keep professional abilities. What makes us think about is that the objective to improve general skills is very beneficial to professional learning. In terms of cultivating the students ungraded from college to university, special methods of operation should be adopted in colleges and universities to help students form their own objectives of learning and career, leading them to have more active learning attitude.

\section{Foundation}

The $12^{\text {th }}$ Five-Year Plan of Beijing Education Science Research on Youth Program: Empirical Research on Higher Vocational Students' Academic Achievement Upgraded from College to University in Beijing (CDA13097); Head of Program: Luo Yingxia

\section{References}

An, X. J., Cheng, C., \& Sun, J. J. (2009). A Review of Students' Learning Engagement. Human Resource Management (Academic Edition), 5, 210-213.

Fredricks, J. A., Blumenfeld, P. C., \& Paris, A. H. (2004) School Engagement: Potential of the Concept, State of the Evidence. Review of Educational Research, 74, 59-109. https://doi.org/10.3102/00346543074001059

Li, J. (2010). On the Structure of Employability in College Students and Related Research (pp. 40-45). Master Thesis, Zhengzhou: Henan University.

Liao, Y. G. (2011a). College Students’ Academic Self-Efficacy Regulating the Relationship 
Between Academic Value Outlook and Learning Engagement. Journal of Ningbo University (Education Science Edition), 33, 50-54.

Liao, Y. G. (2011b). Survey on the Preparation and the Status of College Students' Learning Engagement Questionnaire. Journal of Jimei University, 12, 39-44.

Liu, S. T., \& Yin, X. P. (2001). On Analysis of Individual Factors of Influencing College Students' Employment. Journal of Zhuzhou Institute of Technology, 4, 59-61.

Song, G. X. (2008). Measurement and Analysis of College Graduates' Employability Skills. Chinese Journal of Population Science, 3, 64-72.

$\mathrm{Su}, \mathrm{J}$. (2014). On the Influencing Factors Analysis of College Students' Learning Engagement on Employability (pp. 18-23). Beijing: Beihang University.

Sun, W. W. (2009). On Influence of High School Students Everyday Academic Resilience and Learning Engagement on Academic Performance (pp. 23-24). Changchun: Northeast Normal University.

Sun, X. B. (2010). The National Medium and Long-Term Educational Reform and Development Plan (2010-2020). Beijing: China Legal Publishing House.

Tian, W. D. (2002). On How to Improve Employment. Health Vocational Education, 10, 22-24.

Wang, X. J. (2011). The Study on the Relationship among College Students' Achievement Goal Orientation, Academic Self-Efficacy and Learning Engagement (p. 18). Harbin: Harbin Normal University.

Wei. Y. H. (1998). The Study on the Influence of School Factors on Children's Self-Esteem Development. Psychological Development and Education, 2, 12-16.

Xie, F. H. (2010). The Study on the Relationship among College Students' Learning Engagement, Academic Self-Efficacy and Learning Performance. Master's Thesis, Shenyang: Shenyang Normal University.

Xie, Z. Y. (2005). On Thinking about How to Cultivate College Students' Employability. Exploring Education Development, 1, 43-44.

Zhang, N. (2012). The Review of Domestic and International Learning Engagement and the Influencing Factors of Schools. Psychological Research, 5, 83-92.

\section{Submit or recommend next manuscript to SCIRP and we will provide best} service for you:

Accepting pre-submission inquiries through Email, Facebook, LinkedIn, Twitter, etc. A wide selection of journals (inclusive of 9 subjects, more than 200 journals)

Providing 24-hour high-quality service

User-friendly online submission system

Fair and swift peer-review system

Efficient typesetting and proofreading procedure

Display of the result of downloads and visits, as well as the number of cited articles

Maximum dissemination of your research work

Submit your manuscript at: http://papersubmission.scirp.org/

Or contact ce@scirp.org 